\title{
Chymotrypsinogen B
}

National Cancer Institute

\section{Source}

National Cancer Institute. Chymotrypsinogen B. NCI Thesaurus. Code C118243.

Chymotrypsinogen B (263 aa, $\sim 28 \mathrm{kDa}$ ) is encoded by the human CT RB1 gene. This protein plays a role in proteolytic processes during digestion of nutrients. 